$1-1-2020$

\title{
The Practice of Law as Christian Discipleship
}

\author{
Nathan Chapman \\ Pope F. Brock Associate Professor in Professional Responsibility University of Georgia, nsc@uga.edu
}

University of Georgia School of Law

Research Paper Series

Paper No. 2019-31

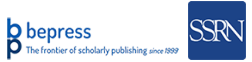

\section{Repository Citation}

Nathan Chapman, The Practice of Law as Christian Discipleship , 47 Pepp. L. Rev. 331 (2020),

Available at: https://digitalcommons.law.uga.edu/fac_artchop/1335

This Article is brought to you for free and open access by the Faculty Scholarship at Digital Commons @ University of Georgia School of Law. It has been accepted for inclusion in Scholarly Works by an authorized administrator of Digital Commons @ University of Georgia School of Law. Please share how you have benefited from this access For more information, please contact tstriepe@uga.edu. 


\title{
The Practice of Law as Christian Discipleship
}

\author{
Nathan S. Chapman*
}

\begin{abstract}
"Can the ordinary practice of law be a religious calling?" In a number of scholarly books and articles, as a teacher, and as a mentor, Robert Cochran has answered this question with a resounding “yes." This Essay, part of a festschrift published in Bob's honor by the Pepperdine Law Review, engages with his work to propose a framework of Christian ethics for reconceiving the practice of law as a form of Christian discipleship. It argues that Christians should understand the practice of law as participation in government-asjudgment, participation that is always fraught with the risks of deceit, injustice, and abuse of power. Christians can nevertheless exercise the theological virtues of faith, hope, and love as they participate in judgment, while trusting that their participation may facilitate those virtues' further development.
\end{abstract}

* Associate Professor, University of Georgia School of Law. Thanks to Bob Cochran and John Inazu for commenting on prior drafts of this Essay. Thanks also to the participants at a 2018 workshop at Pepperdine Caruso School of Law sponsored by the Herbert and Elinor Nootbaar Institute on Law, Religion, and Ethics. 
[Vol. 47: 331, 2020]

The Practice of Law

PEPPERDINE LAW REVIEW

\section{TABLE OF CONTENTS}

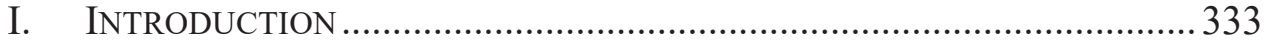

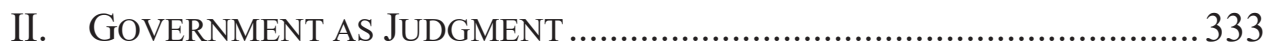

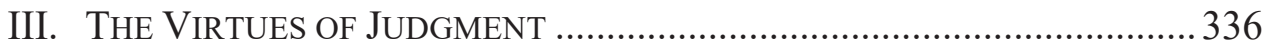

IV. JUdGMENT AND FAITH, Hope, AND Love............................................338

V. CONCLUSION: JUdGMENT AND DisCIPLESHIP …………………….......339 


\section{INTRODUCTION}

Sometimes you see a glimmer through the woods. A torch flickering, a sign of life, a summons even. Bob Cochran's work and friendship have encouraged me along a path of thinking, teaching, and writing about religion and law. In particular, Bob has been at the vanguard of writing, teaching, and facilitating discussion about an important question: "Can the ordinary practice of law be a religious calling?" Bob's writing and, more importantly, his life have answered with a resounding "yes." From within the Christian tradition, Bob has illustrated that Christ might call and fruitfully use his followers as practitioners and teachers of the law.

I would like to outline a framework for a theological ethics of lawyering inspired by Bob's work. The framework has broader implications for a theological ethics of citizenship that I hope to pursue in further research. Like Bob, I am interested less in ethical casuistry and more in Christian discipleship. To that end, the framework is pastoral. My purpose is to encourage Christians who practice law, or, more broadly, those who participate as citizens in a democratic republic, as they do so, to become more like Christ.

\section{GOVERNMENT AS JUDGMENT}

To begin with, I suggest that we orient the practice of law around a theological account of human government. Practicing law is a unique form of participating in government. My own view is that human government is best

1. Robert F. Cochran, Jr., Introduction: Can the Ordinary Practice of Law Be a Religious Calling?, 32 PEPP. L. REV. 373 (2005) [hereinafter Cochran, Religious Calling]; see also LAWYERS, CLIENTS, AND MORAL RESPONSIBILITY (Thomas L. Shaffer \& Robert F. Cochran, Jr. eds., 2d ed. 2009); Robert F. Cochran, Jr., Jesus, Agape, and Law, in AgAPe, JustiCE, AND LAW: How Might CHRISTIAN LOVE SHAPE LAW? 13 (Robert F. Cochran, Jr. \& Zachary R. Calo eds., 2017) [hereinafter Cochran, Jesus, Agape, and Law]; Robert F. Cochran, Jr. \& Dallas Willard, The Kingdom of God, Law, and the Heart: Jesus and the Civil Law, in LAW AND THE BIBLE: JustiCE, MERCY, AND LEGAL InSTITUTIONS 151 (Robert F. Cochran, Jr. \& David VanDrunen eds., 2013). See generally Robert F. Cochran, Jr., Catholic and Evangelical Supreme Court Justices: A Theological Analysis, 4 U. St. Thomas L. Rev. 296 (2006); Robert F. Cochran, Jr., Christian Traditions, Culture, and Law, in Christian Perspectives on Legal Thought 242 (Michael W. McConnell, Robert F. Cochran, Jr. \& Angela C. Carmella eds., 2001); Robert F. Cochran, Jr., Lawyers and Virtues: A Review Essay of Mary Ann Glendon's A Nation Under Lawyers: How the Crisis in the Legal Profession is Transforming American Society and Anthony T. Kronman's The Lost Lawyer: Failing Ideals of the Legal Profession, 71 NOTRE DAME L. REV. 707 (1996) [hereinafter Cochran, Lawyers and Virtues] (commending Mary Ann Glendon and Anthony T. Kronman on their thoughtful insight into the legal profession and their focus on character and virtues). 
understood, theologically, as a temporary institution, resulting from the human rejection of God's rule, which God nevertheless uses to contain and punish human wrongdoing.

This account of human government is within the mainstream of western Christian political theology. ${ }^{2}$ The Apostle Paul told a group of Roman Christians that God had ordained the government to punish wrongdoing. ${ }^{3}$ The government was God's "servant" for the good of society. There is a straight line from this understanding of human government in western Christian thought from Paul, to Augustine, to John Calvin, to many theologians of our own day. ${ }^{4}$

Oliver O'Donovan, in particular, has argued that God's purpose for the government is captured by the concept of "judgment." the government's sphere to the work that courts do - to issuing judgments in particular cases. Rather, O'Donovan argues that the government's operations, whether defining crimes, distributing licenses, or defending the public, should be evaluated in light of the government's ultimate responsibility to define, prevent, and punish wrongdoing. ${ }^{6}$ What is "wrong" depends on local context alongside universal norms. ${ }^{7}$ For now, I will adopt this theological notion of government as principally concerned with judgment. ${ }^{8}$

I think it is necessary to add something that complicates the mainstream picture. The New Testament does not give a clear vision of whether, and how, a follower of Jesus ought to participate in governmental judgment. Christ told his followers to give to Caesar what was his, but he did not tell them what

2. See, e.g., The Government and the Sword, Ligonier Ministries: LigOniER BloG, https:// www.ligonier.org/learn/devotionals/government-and-sword/ (last visited Sept. 30, 2019) ("As a general rule, earthly governments punish wrongdoing.").

3. See Romans 13:1-7 (New American Standard Version) ("Every person is to be in subjection to the governing authorities. For there is no authority except from God, and those which exist are established by God. . . . But if you do what is evil, be afraid; for [the government] does not bear the sword for nothing.").

4. See, e.g., Augustine, The City of God Against the Pagans 634-93 (R.W. Dyson ed. \& trans., 1998); JOHN CALVIN, InstitUTES OF THE CHRISTIAN RELIGION 650-76 (Henry Beveridge trans., 1989); ERIC Gregory, Politics \& THE Order of Love: AN Augustinian Ethic OF DEMOCRATIC Citizenship (2008); 2 RoBERT W. JENSON, SySTEMATIC THEOlOGY: THE Works OF God 76 (1999); Charles T. Mathewes, A Theology of Public Life 180-83 (2007).

5. Oliver O’Donovan, The Ways of Judgment 3 (2005).

6. Id. at 57-58.

7. See John Howard Yoder, The Politics of Jesus (2d ed. 1994).

8. For now, I will leave open the possibility that the government should also affect "justice," understood as a more robust form of individual right. See, e.g., NiCHOLAS WOLTERSTORFF, JustiCE: RightS AND WRONGS 12-13 (2008). 
belonged to Caesar. The New Testament makes it plain that followers of Christ are to forsake their own rights, to turn the other cheek, to lay down their lives. $^{9} \quad$ Yet participating in judgment entails enforcing rights, punishing wrongdoers, and, sometimes, taking lives. ${ }^{10}$ This would seem to put Christians who participate in the exercise of judgment in something of a bind: they are called to do something for others they are forbidden to do for themselves. ${ }^{11}$

Christians have sought to resolve this tension in a variety of ways. Some eschew governmental participation. ${ }^{12}$ As Cochran has noted, the classic justification for Christian participation in government points back to Jesus's ethic of love: sometimes love requires wielding the sword on behalf of the community to protect victims. ${ }^{13}$ Paul tells the Christians in Rome to "never avenge [themselves]"14 but simultaneously makes it clear that God institutes and uses "the governing authorities"15 "to execute wrath on the wrongdoer."16 Perhaps this makes a space for Christians to forgo vengeance against their personal enemies, yet to serve as God's instruments of vengeance against "wrongdoer[s]." ${ }^{\prime \prime}$ As Cochran has put it, "[u]nder Jesus' teaching, the mindset is the same in each setting - the Christian should seek the good of other people, both enemies and victims." 18

Whether this logic resolves or restates the dilemma is open to debate. If loving a victim requires executing vengeance, why not when the victim is oneself? Such a neat division of personal and political vengeance may call for a form of role morality that tests the limits of psychological coherence.

The tension may be felt especially keenly by Christians in a democratic republic. ${ }^{19}$ For them, discipleship and citizenship are fully democratized. Put plainly, they are called to be faithful Christians and good citizens. Without attempting to resolve this problem, it is sufficient at this point to note that in a democratic republic, all those with political rights and responsibilities, such

\footnotetext{
9. Matthew 5:39-40; John 15:13; 1 Corinthians 6:1-9.

10. Cochran, Religious Calling, supra note 1, at 380.

11. Cochran, Jesus, Agape, and Law, supra note 1, at 34.

12. See Stanley Hauerwas, The Peaceable Kingdom: A Primer in Christian Ethics (2016); YODER, supra note 7, at 207-09.

13. O'DonOVAN, supra note 5, at 85-87.

14. Romans 12:19.

15. Id. at $13: 1$.

16. Id. at 13:4.

17. Id.

18. See Cochran, Jesus, Agape, and Law, supra note 1, at 35.

19. Id. at 34 .
} 
as the rights and responsibilities of voting and jury service, participate to some extent in the exercise of judgment. Lawyers do so extensively, and on a daily basis.

\section{THE VIRTUES OF JUDGMENT}

Having reoriented the practice of law as a form of participating in judgment, we are in a better position to understand it as a vocation. I want to argue, in the first place, that Christians should practice law as anyone else should, through the development and exercise of the virtues of practical judgment, truthfulness, and mercy. All lawyers should prioritize the development of these virtues and should develop them to a higher degree than those who participate in judgment only occasionally. These virtues are not unique to Christians, so I will not spend a great deal of time on them.

Briefly, then: by practical judgment I mean roughly what virtue ethicists mean by phronesis - the ability to choose good ends and the best way to achieve them. ${ }^{20}$ A lawyer with practical judgment can identify the nature of a client's problem, and choose the best way to solve it from among the options on offer. Good lawyers know that clients come to them with problems, not necessarily "legal issues." Whether they give rise to legal questions, or some other sort of question, or both, is the lawyer's job to sort out. Litigation, in all its forms, is only one tool in the lawyer's problem-solving toolkit. Practical judgment is the ability to accurately assess which tool to use, and when. ${ }^{21}$

By truthfulness I mean the virtues of accuracy and sincerity. ${ }^{22}$ Lawyers should develop and exercise the capacities to describe facts and law accurately and to speak sincerely. ${ }^{23}$ This goes beyond the duties of candor required by ordinary "professional responsibility." 24 The virtue of accuracy must include

\footnotetext{
20. See 2 Aristotle, Nichomachean Ethics, in THE COMPlete Works OF ARISTOTLE 1729, 1799-1800 (Jonathan Barnes ed., 1984); see also ALISDAIR MACINTYRE, AFTER VIRTUE: A STUDY IN MORAL THEORY (2d ed. 1984).

21. See Lawrence B. Solum, Virtue Jurisprudence: A Virtue-Centered Theory of Judging, 34 Metaphilosophy 178, 192 (2003); Brett G. Scharffs, Law as Craft, 54 VAND. L. ReV. 2245, 2271 (2001); Cochran, Lawyers and Virtues, supra note 1, at 715-21.

22. See generally BERNARD WiLliams, TRUTH AND TRUTHFULNESS 123, 172 (2004) (discussing important attributes of truth and truthfulness and expanding on what accuracy and sincerity mean in this context).

23. See generally Cochran, Lawyers and Virtues, supra note 1, at 717 (discussing the skills required in the study and practice of law).

24. See generally Charles W. Wolfram, The Code of Professional Responsibility as a Measure of Attorney Liability in Civil Litigation, 30 S.C. L. REV. 281, 284 (1979) (clarifying the three stated
} 
the ability to identify when the law does not measure up to the community's moral norms, or to its stated purposes. ${ }^{25}$ Wrongdoing, and the government's proper response to it, is inherently local, and lawyers should be attuned to this. As a concrete example, consider the disparate punishment for possession and sale of crack cocaine that was long baked into federal criminal law. Lawyers are better positioned than others, by virtue of training, habit, and proximity, to recognize that such punishment does not reflect the norms used to justify it.

Mercy is a concept that requires a bit more unpacking. ${ }^{26}$ By mercy we might mean (1) equity; (2) compassion; or (3) forgiveness, understood as the free cancelation of moral debt. Theologians disagree about whether the government can or ought to engage in forgiveness, ${ }^{27}$ so for now I want to put that to the side and focus on equity and compassion.

Equity, as I am using it, means moderating a strict application of a general rule to account for the unique facts of a case. ${ }^{28}$ For instance, taking into account mitigating factors during sentencing. ${ }^{29}$ This form of "mercy," such as it is, is probably best understood as an aspect of accurate judgment. ${ }^{30}$

Mercy-as-compassion, however, bears a closer resemblance to the mercy in the command of the prophet Micah to "act justly,... love mercy, and ... walk humbly with ... God." 31 Such mercy is empathy for those subject to judgment. ${ }^{32}$ They are not social outcasts, cogs in the wheels of justice, or means to an end. They are the object not only of judgment, but of God's

standards in the Code).

25. See, e.g., LAWYERS, CLIENTS, AND MORAL RESPONSIBILITY, supra note 1, at 89-90 (noting that, in the novel To Kill a Mockingbird, Atticus Finch was not truthful about Bob Ewell's death because he was protecting Boo Radley from public notice; Finch believed he was "protecting the weak").

26. See generally LAWYERS, CLIENTS, AND MORAL RESPONSIBILITY, supra note 1, at 71 (defining mercy's defining aims as "care, concern, and contribution to the positive development and flourishing of others").

27. Compare John Inazu, No Future Without (Personal) Forgiveness: Reexamining the Role of Forgiveness in Transitional Justice, 10 HuM. RIGHTS REV. 316, 317 (2009) (finding that the government may forgive wrongdoers because wrongdoers cause public injuries), with Martha Minow, Forgiveness, Law, and Justice, 103 CAL. L. REV. 1615, 1628-29 (2015).

28. See Equity, Black's LAW DictionARY (9th ed. 2009) ("The recourse to principals of justice to correct or supplement the law as applied to particular circumstances.").

29. William Perkins, A Treatise of Christian Equitie, in From IrEnAEUs to Grotius: A SOURCEBOOK In CHRISTIAN POLITICAL THOUGHT 100-1625, 771, 772-77 (Oliver O'Donovan \& Joan Lockwood O’Donovan eds., 1999).

30. Jeffrie G. Murphy, Mercy and Legal Justice, 4 Soc. PHIL. \& POL'Y 1, 5-7 (1986).

31. Micah 6:8 (New International Version).

32. See Michael Welker, The Power of Mercy in Biblical Law, 19 J.L. \& REL. 225, 230-33 (2014). 
eternal love. Such a virtue of mercy is available to all lawyers, regardless their religious tradition, but it has special valence for those who know the God of Jesus Christ.

\section{JUdGMENT AND FAITH, HoPE, AND LOVE}

We are now in a position to discuss the relationship between the spiritual virtues of faith, hope, and love, and the practice of law. This will pave the way for a reflection on the practice of law as a form of discipleship.

I take it for granted that the development and exercise of the theological virtues of faith, hope, and love are an aspect of Christian discipleship, ${ }^{33}$ which itself is the formation of the soul to the image of Christ. ${ }^{34}$ As Aquinas maintained, these virtues are made available by the supernatural work of God in the life of the believer. ${ }^{35}$ Christians can of course develop them without participating in government. Yet, I would argue that government is an underappreciated sphere for the development and exercise of the theological virtues. The reason is simple: human government, though used by God, is imperfect. ${ }^{36}$ Human judgment is beset by failures of will, knowledge, memory, and imagination. The best it may do is to approximate God's judgment. It is a stopgap for the time between the times of God's uncontested reign. ${ }^{37}$ This is why Augustine's judge wept: the tools of human judgment are insufficient to the task, and the judge knows it. ${ }^{38}$

How does the Christian judge endure such suffering? Perceiving human government, and our participation in it, as part of God's plan for the world requires the exercise of faith. Lawyers not only see but unavoidably contribute to judgment's imperfection. Can this imperfect human endeavor-government, with all its surfeit of lies, violence, and banal negligence-really be God's servant for our good, as Paul asserted? To see human judgment as such requires faith.

To believe that God will one day judge our judgment, with perfect accuracy and mercy, requires hope. Our mistaken judgment is not the last word.

33. 1 Corinthians 13:13.

34. Galatians 5:24, 6:14; Luke 9:23, 14:27; Mark 8:34; Matthew 10:38; Romans 8:30.

35. THOMAS AQuinas, Summa THEOLOGIAE 240 (questioning what virtues are made available by the work of God in the first part of question 62).

36. See Mark 10:42 (Jesus acknowledging that rulers were flawed).

37. See Titus 3:12.

38. See Augustine, City of God, supra note 4, at 926-28. 
Christ is the last word. This is not an excuse for negligence or libertinism. It is the assurance that God in Christ is busy making all things-including judgment-new. ${ }^{39}$

In the meantime, participating in judgment requires love for God, for those whom judgment protects, and for those whom it corrects. This is where, in my view, mercy-as-forgiveness ought to enter the picture. Christian lawyers should be quick to let go of personal grievances, of course. But more than this: they should urge their clients in civil cases to pursue reconciliation if at all possible. The harder question for forgiveness is its role in criminal law. My inclination is that prosecutors and judges should not take forgiveness into account because it is not theirs to give. Victims may, of course, forgive. The harder question is whether and when society should forgive an offender, and how the legal system should implement such forgiveness.

\section{CONCLUSION: JudgMENT AND DisciPLESHIP}

I want to conclude by suggesting that participating in judgment is not only a unique way to exercise the spiritual virtues of faith, hope, and love, but also a unique way to develop them. In short, enduring the "futility" of judgment with faith, hope, and love helps to conform lawyers into the image of Christ.

Christians experience the imperfections of human judgment as part of the corruption of creation. As Paul wrote to the Romans, "the creation was subjected to futility" "in hope that the creation itself will be set free from its bondage to corruption and obtain the freedom of the glory of the children of God." ${ }^{40}$ "The whole creation has been groaning together in the pains of childbirth until now," he says. ${ }^{41}$ This passage is ordinarily interpreted to be about the nonhuman created order - the earth, animals, plants, and the like. I would suggest that Paul's sentiment applies equally to human government. Though used by God, it is nonetheless subjected to "futility" and "the bondage of corruption." ${ }^{42}$ Government is not only imperfect, but imperfectable, a frustrated tower to the sky.

But the futility of creation is not the last word. Paul connects it to discipleship. Those with the "first fruits of the Spirit... groan inwardly as we

\footnotetext{
39. 2 Corinthians 5:17; Galatians 6:15; Revelations 21:5.

40. Romans 8:20-21.

41. Id. at 8:22.

42. Id. at $8: 21$.
} 
[Vol. 47: 331, 2020]

The Practice of Law

PEPPERDINE LAW REVIEW

wait eagerly for adoption as sons, the redemption of our bodies." 43 It is precisely because of our weakness, the gap between our vision and God's, that the Spirit "intercedes for us with groanings too deep for words . . . according to the will of God."44 "For," as Paul reminds us, "those whom he foreknew he also predestined to be conformed to the image of his Son." 45

God uses the gulf between the way things are and the way things will be to transform us into the image of Christ. It takes faith, hope, and love-gifts of God-to participate in the practice of law as a Christian. And it is bound to be a trial - even putting aside the ordinary temptations of materialism, careerism, and power. Even when a lawyer sees his or her work within God's economy of creation and redemption, the government's exercise of judgment is bound to be half-measured, inaccurate, and, at times, heart-breaking. Yet God uses that trial to reinforce the spiritual virtues, making us more like Christ.

And so perhaps Bob's question, "Can the ordinary practice of law be a religious calling?" is best answered this way: God can use even the practice of law to make ordinary disciples.

43. Id. at $8: 23$.

44. Id. at 8:26-27.

45. Id. at $8: 29$. 